\title{
DETERMINATION OF WEIBULL PARAMETERS AND ANALYSIS OF WIND POWER POTENTIAL IN COASTAL AND NON-COASTAL SITES IN AKWA IBOM STATE
}

\author{
Y. N. Udoakah ${ }^{1,}{ }^{*}$ and U. S. Ikafia ${ }^{2}$ \\ 1,2 Dept. of Electrical/Electronics \& Computer EnGR', University of Uyo, Uyo, AKWA Ibom STATe, NiGERIA \\ E-mail addresses: ${ }^{1}$ yeobongudokah@uniuyo.edu.ng, ${ }^{2}$ ikafiaubong@gmail.com
}

\begin{abstract}
The wind power potential and its viability for commercial energy production across two sites Eket (Latitude 4033'N \& Longitude 7058'E) and Uyo (Latitude $5^{\circ} 18^{\prime} 53.7^{\prime \prime} \mathrm{N} \&$ Longitude 7059'39.29'E) in Akwa Ibom State were investigated. Using data obtained from the Nigeria Meteorological Agency (MIMET) for both locations for a period of four years (20102013), a statistical analysis was performed. The Weibull Distribution Function was used to determine the monthly and yearly wind speed. Resulting from the analysis, the values of the average wind speed, the average daily wind power, the shape parameter (k) and the scale factor(c) were obtained to be $6.7 \mathrm{~m} / \mathrm{s}$ and $4.3 \mathrm{~m} / \mathrm{s}, 0.91 \mathrm{MW}$ and $0.25 \mathrm{MW}, \mathrm{K} \sim 5.4$ and 2.1 , and $c \approx 8.8 \mathrm{~m} / \mathrm{s}$ and $4.6 \mathrm{~m} / \mathrm{s}$ respectively, for Eket and Uyo. Also, the annual electricity generation was projected to be $40.88 \mathrm{MWh}$ 10.80 MWh respectively, for Eket and Uyo. The Weibull distribution can be relied on for accurate prediction of wind energy output and resulting from the predicted values, Eket a coastal area was assessed to be viable for commercial wind power production compared to Uyo a non-coastal area.
\end{abstract}

Keywords: Wind power potential, Energy production, Weibull distribution, Wind speed, Statistical analysis, Coastal \& Non-coastal area

\section{INTRODUCTION}

The recent fall in the prices of crude oil globally and the continuous instability in most parts of the oil rich regions of the world has given a tremendous boost to the quest for sustainable energy sources. The 2016 International Energy Agency (IEA) world energy outlook report assess the growth in the renewable energy sector as quite impressive [1]. With respect to wind turbine installations, about $63,135 \mathrm{MW}$ of wind power capacity was added globally in 2015 indicating a $23.2 \%$ increase from the 51,230 MW installed in 2014 [2]. Projections made by the U.S. Department of Energy indicate that wind energy will provide $20 \%$ of U.S. electricity need by 2030 [3]. In Europe, the European Wind Energy Association's scenarios show that wind energy will meet $15.7 \%(230 \mathrm{GW})$ and $28.5 \%(400 \mathrm{GW})$ of European electricity demand by 2020 and 2030, respectively [4]. In China, the forecast is not different as the report of the National Development and Reform Commission of People Republic of China foresees wind power capacity reaching 200 GW by $2020,400 \mathrm{GW}$ by 2030 , and $1000 \mathrm{GW}$ by 2050 [5]. These figures clearly portray the fast pace at which wind energy is entrenched as part of the broader worldwide energy system. Expectedly, the annual record achieved and other projections made was not driven by developing countries that are ironically blessed in great abundance with these resources and are the ones in dire need of energy access as indicated in [1].

The energy access situation in Nigeria has not significantly improved, neither has reasonable progress been made in her quest to develop and exploit her abundant renewable energy sources. For instance, a study on sustainably meeting the energy needs of Nigeria: the renewable energy option was carried out by [6] and the conclusion was that Nigeria was sustainably rich and ought not to be lacking power. Regarding the country's wind energy potential and its viability for power generation, various studies have shown and also proved that depending on the location, wind power was viable for power generation both at small and commercial scale [7-13]. Data from these studies indicates that wind speed ranges from about 2 to 12.5 $\mathrm{m} / \mathrm{s}$ with indications of low wind speed regime in the South with exception of Enugu and high wind speed regime in most part of the North and South West having a predicted average yearly speed within the range of 5-6 $\mathrm{m} / \mathrm{s}$ as seen in Figure 1. Clearly, these results from the literature reviewed are indicative of the wind resource assessment in non-coastal areas and show great potential for on-shore wind energy generation using 
micro and small turbine. However, for commercial viability, an off-shore wind resource mapping would be required.

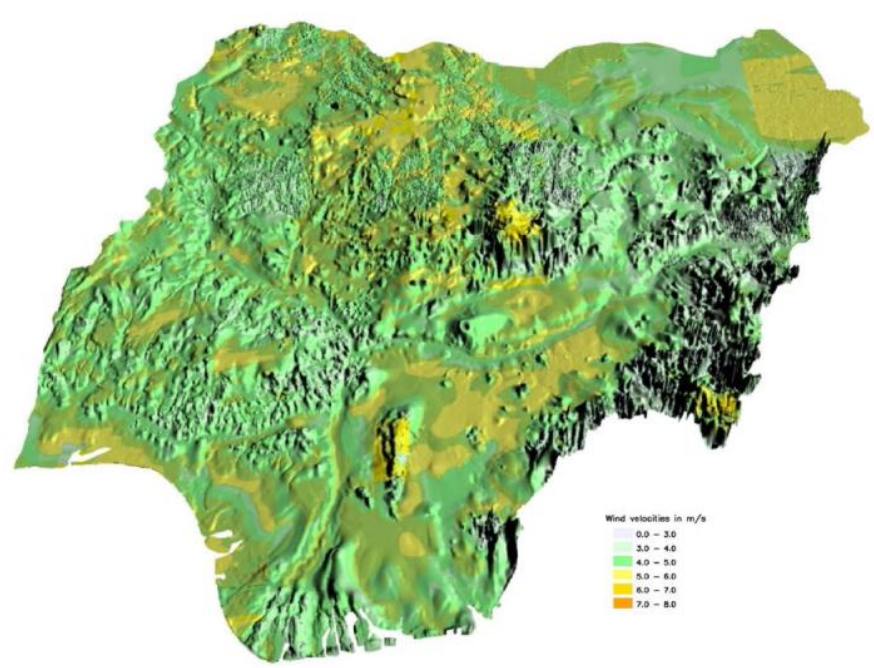

Figure 1:3D Wind map of Nigeria 80 m above the ground. Source [14]

In coastal areas, the differing heat capacities of land and water results in different rates of heating and cooling leading to air flow both during the day and night. Assessing the wind statistical properties and speed is essential to the optimum prediction of its energy output and wind turbine behaviour. The energy that a wind turbine is likely to produce is dependent not only on its wind speed-power curve but also on the wind speed frequency distribution at the location of interest. With respect to most of the wind resource assessment carried out across the various locations in Nigeria, it is evident from the reviewed literature that most studies on wind potential assessment had focused mainly on non-coastal areas even among the coastal regions while a few others provided little and insufficient information about the coastal areas. For instance, it was observed that the studies on the wind resource assessment so far carried out for Akwa Ibom State as documented in [28-30] only made reference to Uyo, the state capital. Even though Akwa Ibom is among the coastal States, there are however, about six core coastal Local Governments in the State. Hence using the wind resource assessment of Uyo, a non-coastal Local Government as a yard stick for evaluating the wind potential of Akwa Ibom as a coastal State is not appropriate. It is in view of this, that the wind resource assessment for a coastal and non-coastal site in Akwa Ibom was conducted in order to fill the missing knowledge gap and also create the much needed awareness regarding the commercial viability of the wind energy potential in the coastal areas of the State. Also, this study seeks to determine the weibull parameters and also perform an analysis of the wind speed at both the coastal and non-coastal sites in Akwa Ibom State.

\section{MATERIALS AND METHOD}

Wind resource assessment for the effective application of wind turbines requires a careful study of some basic factors like; the geographical distribution of wind speeds, characteristic parameters of the wind, topography, local wind flow and wind speed measurement. The daily wind speed data used in this study was obtained from the Nigeria Meteorological Agency (MIMET) for Uyo (Latitude 5०18'53.7'N; Longitude 7059'39.29"E) and Eket (Latitude $4^{0} 33^{\prime} \mathrm{N}$ and Longitude $7^{05} 8^{\prime} \mathrm{E}$ ) for a period of four years 2010 to 2013. The wind speed data was measured continuously with an Anemometer at a height of $10 \mathrm{~m}$. The data obtained provides daily average wind speed distributions of the location for the stated period from which average values were computed. Using the two-parameter Weibull function, the frequency distribution of the measured data was studied.

\subsection{Wind Speed Frequency Distribution}

Wind energy site assessment evaluates the potential for a given site to produce energy from wind turbines. There are several approaches to investigate the wind resource within a given area of land and the preferred approach is defined by objectives of the wind energy program [15].

\subsection{Wind Speed Data: Weibull Distribution}

Since wind is not steady, calculating the mean power delivered by a wind turbine from its power curve requires the knowledge of the probability density distribution of the wind speed which is simply the distribution of the proportion of time spent by the wind within narrow bands of wind speed. In statistical modeling of wind speed variation, the Weibull twoparameter (shape parameter $\mathrm{k}$ and scale parameter $\mathrm{c}$ ) function has been widely applied by many researchers. The probability density function of the Weibull distribution is given by [16] as:

$$
f(v)=\left(\frac{k}{c}\right)\left(\frac{v}{c}\right)^{k-1} \exp \left[-\left(\frac{v}{c}\right)^{k}\right]
$$

In $(1), f(v)$ is the probability of observing wind speed $v$, $\mathrm{k}$ is the dimensionless Weibull shape parameter and $\mathrm{c}$ is the Weibull scale parameter, which have reference values in the units of wind speed. The corresponding cumulative probability function of the Weibull distribution is expressed by [16-17] as:

$$
F(v)=1-\exp \left[-\left(\frac{v}{c}\right)^{k}\right]
$$

In (2), $\mathrm{v}$ is the wind speed, $\mathrm{k}$ is the shape parameter and c is the scale parameter. Here, $f(v)$ represents the fraction of time (or probability) for which the wind blows with a velocity $\mathrm{V}$, and $F(v)$ indicates the fraction of 
time (or probability) that the wind velocity is equal or lower than V [18]. From eqn. (1) and (2) it is evident that $\mathrm{k}$ and $\mathrm{c}$ are the factor affecting the wind spectra within a given regime.

\subsection{Determination of Weibull Parameters:}

Four methods of determining the Weibull parameters are given by [19]. These include:

\subsubsection{Empirical Method}

Shape and scale parameter $\mathrm{k}$ and $\mathrm{c}$ are measured in this method by the following equations:

$$
\begin{gathered}
k=\left(\frac{\sigma}{\overline{V_{m}}}\right)^{-1.086} \\
c=\frac{\bar{v}}{\Gamma\left(1+\frac{1}{k}\right)} \\
\Gamma(x)=\int_{0}^{\infty} t^{x-1} e^{-t} d t \\
\Gamma(x)=\sqrt{2 \pi} x \cdot x^{x-1} \cdot e^{-x} \cdot\left(1+\frac{1}{12} x+\frac{1}{288} x^{2}-\frac{139}{58140} x^{3}\right. \\
+\cdots)
\end{gathered}
$$

Shape and scale parameters in this method are estimated from the mean wind speed $\left(\mathrm{V}_{\mathrm{m}}\right)$ and standard deviation $(\sigma)$ of wind data $[20]$.

\subsubsection{The Maximum Likelihood Method}

The Weibull distribution can be fitted to time series wind data using the maximum likelihood method as suggested by [21]. The shape parameter $\mathrm{k}$ and the scale parameter $c$ are estimated using the following two equations:

$$
\begin{gathered}
k=\left(\frac{\sum_{i=1}^{n} v_{i}^{k} \ln \left(v_{i}\right)}{\sum_{i=1}^{n} v_{i}^{k}}-\frac{\sum_{i=1}^{n} \ln \left(v_{i}\right)}{n}\right)^{-1} \\
c=\left(\frac{1}{n} \sum_{i=1}^{n} v_{i}^{k}\right)^{1 / k}
\end{gathered}
$$

In (7) and (8), $v_{i}$ is the wind speed in time step $\mathrm{i}$ and $\mathrm{n}$ is the number of non-zero wind speed data points. Eq. (7) must be solved using an iterative procedure $(\mathrm{k}=2$ is a suitable initial guess), after which Eq. (8) can be solved explicitly. Eq. (7) is applied only to the non-zero wind speed data points.

\subsubsection{The Modified Maximum Likelihood Method}

When wind speed data are available in frequency distribution format, a variation of maximum likelihood method can be applied. The Weibull parameters are estimated using the following two equations:

$$
\begin{gathered}
k=\left(\frac{\sum_{i=1}^{n} v_{i}^{k} \ln \left(v_{i}\right) P\left(v_{i}\right)}{\sum_{i=1}^{n} v_{i}^{k} P\left(v_{i}\right)}-\frac{\sum_{i=1}^{n} \ln \left(v_{i}\right) P\left(v_{i}\right)}{P(v \geq 0)}\right)^{-1} \\
c=\left(\frac{1}{P(v \geq 0)} \sum_{i=1}^{n} v_{i}^{k} P\left(v_{i}\right)\right)^{1 / k}
\end{gathered}
$$

Here, $v_{i}$ is the wind speed, $\mathrm{P}\left(v_{i}\right)$ represents the Weibull frequency, $p(v \geq 0)$ is the probability that the wind speed equals or exceeds zero. Eq. (9) must be solved iteratively, after which eq. (10) can be solved explicitly.

\subsubsection{Energy Pattern Factor Method}

This is a new method suggested by [22]. It is related to the averaged data of wind speed. This method has simpler formulation, easier implementation and also requires less computation. The method is defined by the following equations:

$$
\begin{gathered}
E_{p f}=\frac{\overline{v^{3}}}{\left(\overline{v^{3}}\right)} \\
k=1+\frac{3.69}{\left(E_{p f}\right)^{2}} \\
\bar{v}=c \Gamma(1+1 / k)
\end{gathered}
$$

Eqn. (11) is known as the energy pattern factor method which can be solved numerically or approximately by power density technique using Eq. (12). Once $k$ is determined, c can be estimated using Eqn. (13). In this work, the Weibull distribution parameters in terms of $\mathrm{k}$ and $\mathrm{c}$ and mean wind speed were determined for both locations using empirical method because of its ease of computation.

\subsection{Wind Power Calculation and Estimation}

According to [23], the extracted power from the wind is given by:

$$
P_{\text {avail }}=\frac{1}{2} \rho A V^{3} C_{p}
$$

Where $P_{\text {avail }}$ is the Available Power in the wind, $\rho$ is the Air density $\left(1.23 \mathrm{~kg} / \mathrm{m}^{3}\right)$, A is the swept Area of the turbine given by: $A=\pi r^{2}$; Where radius, $\mathrm{r}$ is equal to the blade length. The rotor diameter is related to the blade length and the swept area. Thus; Rotor diameter $/ 2=$ Blade length; Blade length ${ }^{2} * \pi=$ Swept area. Doubling the swept area means doubling the power output. However, if the wind speed doubles then the power output increases by a factor of 8 , which simply means producing 8 times more power; $\mathrm{V}$ is the mean wind speed, and $C_{p}$ is the Power coefficient given by 0.59 .

Annual energy output (AEO) is given by [24] to be;

$$
\mathrm{AEO}=\frac{1}{2} \rho A V^{3} C_{p}(8,760 h r s / \text { year })
$$

\subsection{Wind Power Density (WPD):}

The Wind Power density measured in $\mathrm{W} / \mathrm{m}^{2}$ indicates how much energy is available at the site for conversion by a wind turbine. It is given by;

$$
\frac{P}{A}=\frac{1}{2} \rho V^{3}
$$

The above expression is dependent on the air density and the wind speed but independent of the size of the turbine rotor or the efficiency or other characteristics of the wind turbine [25]. 
Using equation 17 , a rough estimate of the electricity production (in kilowatt hours per year) from a number of wind turbines at any site can be obtained if the mean annual wind speed is known [26]. Annual electricity production:

$$
\mathrm{KV}_{\mathrm{m}}{ }^{3} \mathrm{~A}_{\mathrm{t}} \mathrm{T}
$$

In (17), $\mathrm{k}=3.2$ and a factor based on typical turbine performance characteristics and an approximate relationship between mean wind speed and wind speed frequency distribution, $V_{m}$ is the site annual mean wind speed in $\mathrm{ms}^{-1}, \mathrm{~A}_{\mathrm{t}}$ is the swept area of the turbine in $\mathrm{m}^{2}$ and $\mathrm{T}$ is the number of turbines. Using the wind speed value, air density and number of turbines, a Wind Energy Calculation Application was developed using android studio to determine the wind power density, annual electricity production and available wind power.

\section{RESULTS AND DISCUSSION}

In this study, the daily wind speed data for Eket and Uyo, representing coastal and non-coastal sites in Akwa Ibom State, Nigeria, over a period of four years from 2010 to 2013 measured by the Nigeria Meteorological Agency (MIMET) were analysed. The analyses were done using Microsoft Excel and Wind Energy Calculator - an android application developed by the authors using android

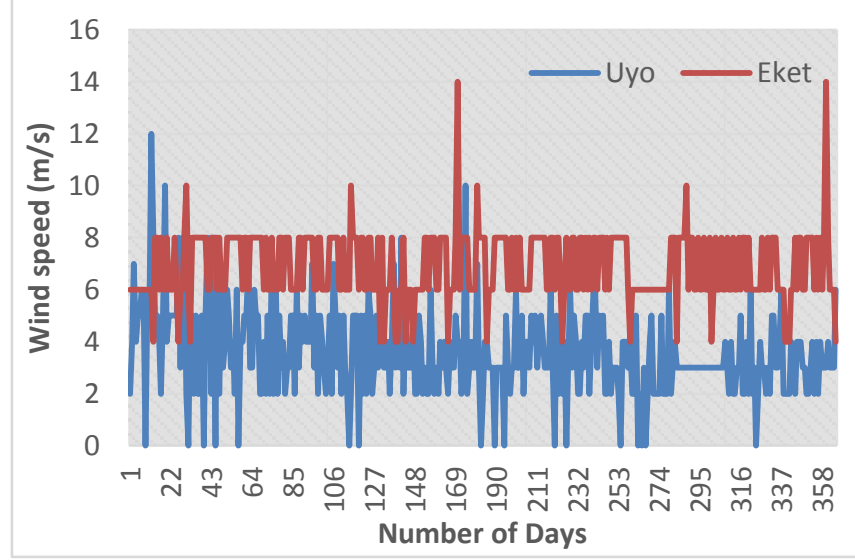

(a) 2010

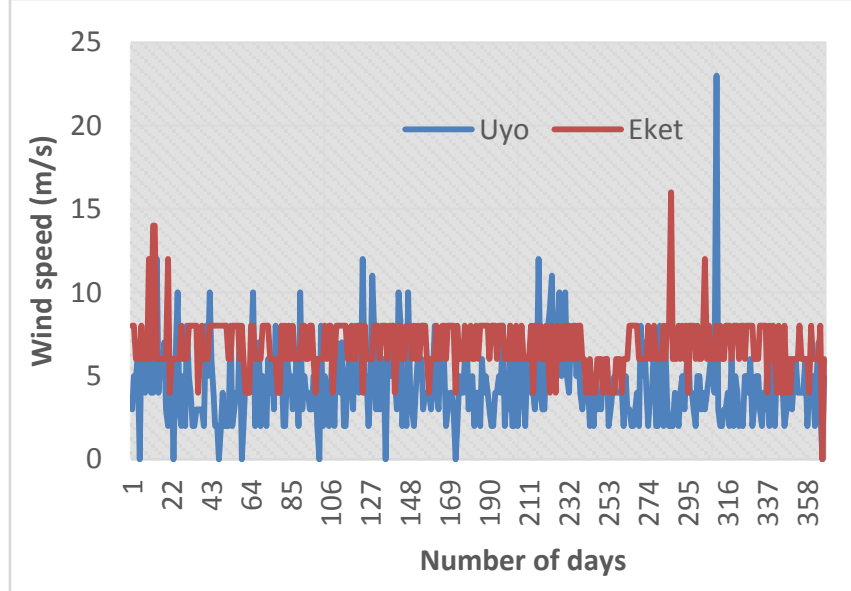

(c) 2012 studio, for the determination of wind power density, annual electricity production and available wind power. The Weibull distribution parameters in terms of $\mathrm{k}$ and $\mathrm{c}$ and mean wind speed were determined for the two locations using empirical method.

Figures $2 \mathrm{a}$ to $2 \mathrm{~d}$ shows the daily mean wind speed variation across the two locations for the various years. The monthly maximum and minimum wind speed values $(\mathrm{m} / \mathrm{s})$ are recorded in Table 1 . By inspection, it can be quickly observed from the Table that the minimum values of wind speed for Eket at any time within the stated period was not below $4 \mathrm{~m} / \mathrm{s}$ whereas this was not the case for Uyo as the minimum wind speed values fluctuated between 0 and $2 \mathrm{~m} / \mathrm{s}$. The highest values of wind speed $(16 \mathrm{~m} / \mathrm{s})$ were recorded in the months of September and October of 2012 for Eket, while that for Uyo $(23 \mathrm{~m} / \mathrm{s})$ was recorded in November of the same year.

The yearly variation of the wind speed is presented in Table 2. It can be seen that for the period under review, the highest wind speed of $6.89 \mathrm{~m} / \mathrm{s}$ and $4.96 \mathrm{~m} / \mathrm{s}$ occurred in the year 2010 and 2013, while the minimum wind speed of $6.32 \mathrm{~m} / \mathrm{s}$ and $3.56 \mathrm{~m} / \mathrm{s}$ occurred in the year 2013 and 2010 for Eket and Uyo respectively.

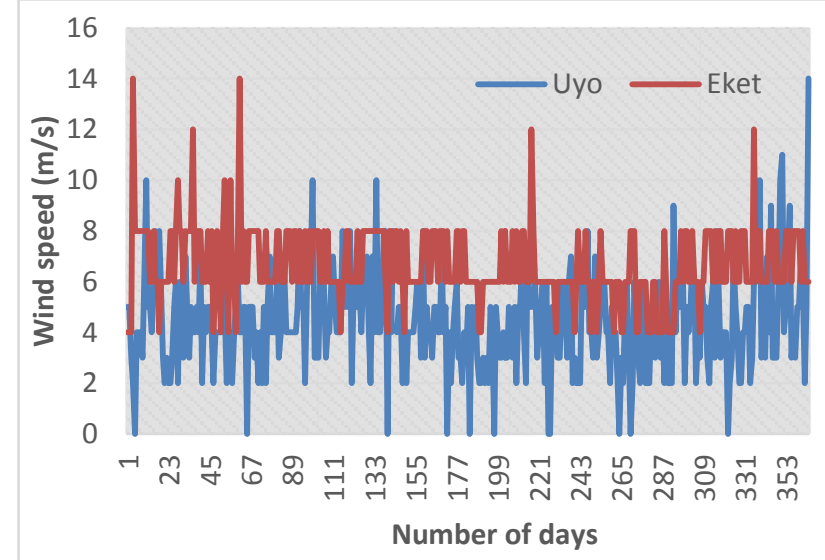

(b) 2011

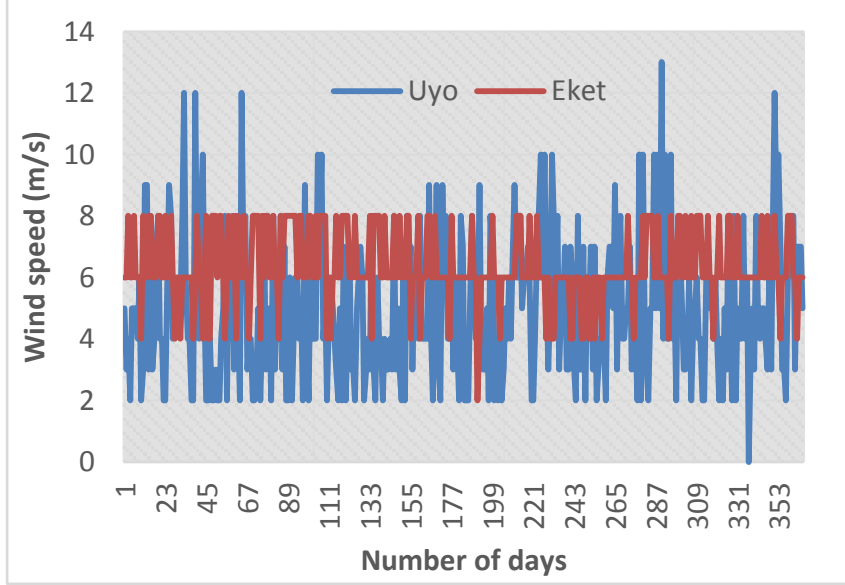

(d) 2013

Figure 2: Daily mean wind speed variation in the two locations between 2010 and 2013 
Determination of Weibull Parameters and Analysis of Wind Power Potential in Coastal and ... Y. N. Udoakah \& U. S. Ikafia

Table 1: Maximum and minimum monthly wind speed $(\mathrm{m} / \mathrm{s})$ for both locations

\begin{tabular}{|c|c|c|c|c|c|c|c|c|c|c|c|c|c|c|c|c|}
\hline & \multicolumn{4}{|l|}{2010} & \multicolumn{4}{|l|}{2011} & \multicolumn{4}{|c|}{2012} & \multicolumn{4}{|l|}{2013} \\
\hline & \multicolumn{2}{|l|}{ UYO } & \multicolumn{2}{|c|}{ EKET } & \multicolumn{2}{|l|}{ UYO } & \multicolumn{2}{|l|}{ EKET } & \multicolumn{2}{|l|}{ UYO } & \multicolumn{2}{|c|}{ EKET } & \multicolumn{2}{|l|}{ UYO } & \multicolumn{2}{|c|}{ EKET } \\
\hline & MAX & MIN & MAX & MIN & MAX & MIN & MAX & MIN & MAX & MIN & MAX & MIN & MAX & MIN & MAX & MIN \\
\hline JAN & 12 & 0 & 10 & 4 & 10 & 0 & 14 & 4 & 12 & 0 & 14 & 4 & 12 & 2 & 8 & 4 \\
\hline FEB & 8 & 0 & 8 & 4 & 7 & 2 & 12 & 4 & 10 & 0 & 8 & 4 & 12 & 2 & 8 & 4 \\
\hline MAR & 7 & 2 & 8 & 6 & 7 & 2 & 14 & 6 & 10 & 2 & 8 & 4 & 12 & 2 & 8 & 4 \\
\hline APR & 7 & 0 & 10 & 6 & 10 & 2 & 8 & 6 & 8 & 0 & 8 & 4 & 10 & 2 & 8 & 4 \\
\hline MAY & 8 & 2 & 8 & 4 & 10 & 2 & 8 & 4 & 12 & 0 & 8 & 4 & 8 & 2 & 8 & 4 \\
\hline JUNE & 10 & 2 & 14 & 4 & 8 & 2 & 8 & 6 & 8 & 0 & 8 & 4 & 9 & 2 & 8 & 4 \\
\hline JUL & 6 & 0 & 8 & 4 & 7 & 2 & 8 & 4 & 8 & 2 & 8 & 4 & 9 & 2 & 8 & 2 \\
\hline AUG & 6 & 0 & 8 & 4 & 8 & 2 & 12 & 4 & 12 & 2 & 8 & 4 & 10 & 2 & 8 & 4 \\
\hline SEPT & 5 & 0 & 8 & 4 & 8 & 2 & 12 & 4 & 8 & 2 & 16 & 4 & 9 & 2 & 8 & 4 \\
\hline OCT & 6 & 2 & 10 & 4 & 9 & 2 & 8 & 4 & 8 & 2 & 16 & 4 & 13 & 2 & 8 & 4 \\
\hline NOV & 6 & 0 & 8 & 6 & 8 & 0 & 8 & 4 & 23 & 2 & 8 & 6 & 8 & 2 & 8 & 4 \\
\hline DEC & 6 & 2 & 14 & 4 & 14 & 2 & 12 & 6 & 7 & 2 & 8 & 4 & 12 & 0 & 8 & 4 \\
\hline
\end{tabular}

Table 2: Yearly average wind speed $(\mathrm{m} / \mathrm{s})$ for both locations

\begin{tabular}{lllll}
\hline & 2010 & 2011 & 2012 & 2013 \\
\hline Uyo & 3.569 & 4.507 & 4.435 & 4.961 \\
Eket & 6.893 & 6.659 & 6.772 & 6.328 \\
\hline
\end{tabular}

Table 3: Geographical coordinate and wind speed

\begin{tabular}{llllllll}
\hline Location & Latitude & Longitude & $\begin{array}{l}\text { Altitude } \\
(\mathrm{m})\end{array}$ & $\begin{array}{l}\text { Average wind } \\
\text { speed (m/s) }\end{array}$ & $\begin{array}{l}\text { Standard } \\
\text { Deviation } \\
(\mathrm{m} / \mathrm{s})\end{array}$ & $\begin{array}{l}\text { Shape } \\
\text { Parameter (k) }\end{array}$ & $\begin{array}{l}\text { Scale } \\
\text { Parameter }(\mathrm{c}) \\
(\mathrm{m} / \mathrm{s})\end{array}$ \\
\hline Eket & $4^{0} 33^{\prime} \mathrm{N}$ & $7^{0} 58^{\prime} \mathrm{E}$ & 157 & 6.7 & 1.40 & 5.4 & 8.8 \\
Uyo & $5^{\circ} 18^{\prime} 53.7^{\prime \prime} \mathrm{N}$ & $7^{0} 59^{\prime} 39.29^{\prime \prime} \mathrm{E}$ & 51.2 & 4.3 & 2.16 & 2.1 & 4.6 \\
\hline
\end{tabular}

Table 4: The Weibull cumulative Distribution Function and Weibull Probability Density Function

\begin{tabular}{lll}
\hline Location & Weibull cumulative Distribution Function, $F(v)$ & Weibull Probability Density Function, $f(v)$ \\
\hline Eket & 0.487311 & 0.072302 \\
Uyo & 0.583373 & 0.178561 \\
\hline
\end{tabular}

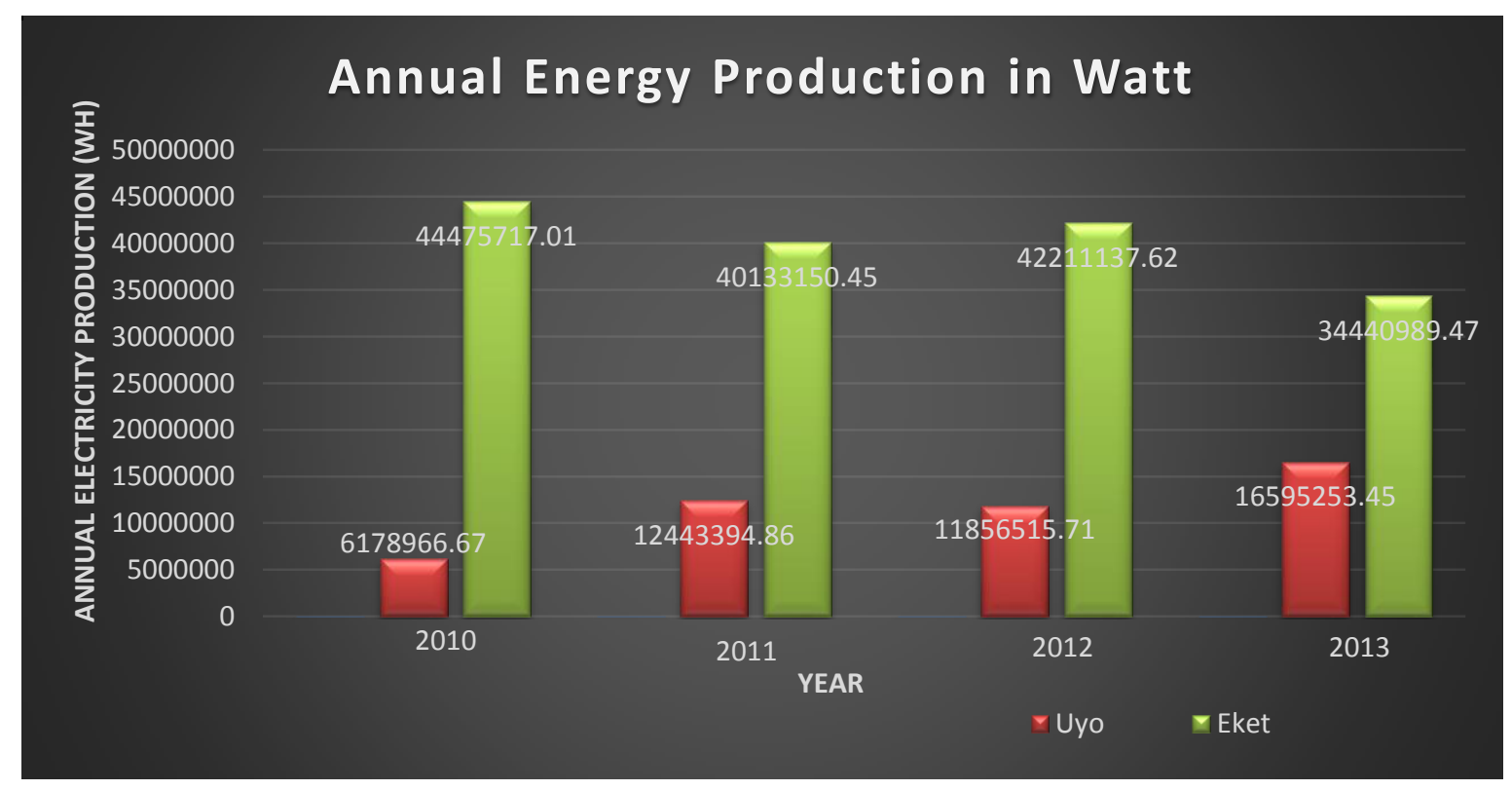

Figure 3: Estimated annual electricity production for both locations 
From Table 3 , the overall yearly mean wind speed is found to be $6.7 \mathrm{~m} / \mathrm{s}$ and $4.3 \mathrm{~m} / \mathrm{s}$ for Eket and Uyo respectively. The values of the standard deviation, the shape parameter $(\mathrm{k})$ and the scale parameter (c) are also presented in Table 3 while the Weibull cumulative distribution function $F(v)$ and Weibull probability density function $f(v)$ are shown in Table 4 . Using the values of the Weibull cumulative distribution function, it is possible to estimate the time that a wind turbine can generate power.

It is generally observed that the pattern of the distribution for Eket has higher values compared to that of Uyo. This reason is very obvious since Eket is a coastal region with a greater wind potential. Using equation 14 and other related parameters from the analysis, the average daily wind power using a turbine blade length of $52 \mathrm{~m}$, was calculated to be $0.91 \mathrm{MW}$ and $0.25 \mathrm{MW}$ for Eket and Uyo respectively, while the annual wind power for both locations was estimated to be 7,936 MW and 2,146 MW respectively. Similarly, the annual electricity production from five (5) wind turbines was estimated using equations 17 .

The plot in Figure 3 and the wind power calculations indicate the highest energy yield at the coastal area of Eket in Akwa Ibom State. Inferring from this, it can be deduced that there is a commercially usable wind potential around the state coastal areas.

\section{CONCLUSION}

The daily measured wind speed for Eket and Uyo, a coastal and non-coastal area were analyzed statistically based on Weibull probability distribution function. The daily and annual wind power estimation was done using a self-developed android application. The Results show that although the pattern of wind speed distribution for the two locations appeared to be similar, averagely, the wind distribution in Eket $(6.7 \mathrm{~m} / \mathrm{s})$ was higher when compared to that of Uyo $(4.3 \mathrm{~m} / \mathrm{s})$. The distributions for both locations are consistent with Raleigh distribution with a shape parameter $\mathrm{k} \sim 5.4$ and 2.1respectively for both locations. The wind power density for Eket at $10 \mathrm{~m}$ height is $181.19 \mathrm{~W} / \mathrm{m} 2$ while that of Uyo is $48.86 \mathrm{~W} / \mathrm{m} 2$, with scale factor (c) of $8.8 \mathrm{~m} / \mathrm{s}$ and $4.6 \mathrm{~m} / \mathrm{s}$ respectively, indicating that Eket would be a perfect site for wind power development for optimum generation and cost effectiveness, since the density value is greater than 100 $\mathrm{W} / \mathrm{m}^{2}$ [16]. Inferring from this, it can be deduced that there is a commercially usable wind potential around the state coastal areas. The Weibull distribution function can be used with acceptable accuracy for prediction of wind energy output required for preliminary design and assessment of wind power plants. The study recommends the deployment of an off-shore wind mapping system to determine the wind potential across these locations. Such information would be beneficial for further investigation of the potential of wind power in Akwa Ibom State and other coastal locations in Nigeria, as offshore wind energy (OWE), located near large and dense coastal electricity demand centers has the potential to provide large amounts of carbon-free power according to [27].

\section{ACKNOWLEDGEMENT}

The authors would like to thank Mr. Joseph Ntekim for assisting with the data collection and other contributions.

\section{REFERENCES}

[1] IEA, "World Energy Outlook 2016" http://www.iea.org/publications/freepublications/ publication/WorldEnergyOutlook2016ExecutiveSu mmaryEnglish.pdfAccessed on January 3, 2017.

[2] Global Wind Energy Council, "Wind energy report" http://www.gwec.net. Accessed on June 18, 2016.

[3] United States Department of Energy, "20\% wind energy by 2030: increasing wind energy's contribution to U.S. electricity supply," Rep. DOE/GO-102008-2567, July 16, 2008.

[4] The European Wind Energy Association, "Pure Power: Wind energy targets for2020 and 2030," http://www.ewea.org. Accessed on September 15, 2016.

[5] Energy Research Institute, National Development and Reform Commission (NDRC) of P. R. China, "China Wind Energy Development Roadmap 2050," http://www.iea.org/papers/roadmaps/china wind. pdf. Accessed on September 15, 2016.

[6] Udoakah, Y. and Umoh M. "Sustainably Meeting the Energy Needs of Nigeria: The Renewable Options", in Proc. IEEE Energycon Conference, Dubrovnik, Croatia, May 13-16, 2014, pp. 326-332. 2014.

[7] Ojosu, J. O. and Salawu, R. I. "An evaluation of wind energy potential as a power generation source in Nigeria", Solar and Wind Technology, 7, pp. 663$673,1990$.

[8] Adaramola, M. S. and O. M. Oyewola."On wind speed pattern and energy potential in Nigeria," Energy Policy, vol. 39, pp. 2501-2506, 2011.

[9] Fadare, D. A. "The application of artificial neural networks to mapping of wind speed profile for energy application in Nigeria", Applied Energy, 87, pp. 934-942, 2010.

[10] Fadare, D. A. "A Statistical Analysis of Wind Energy Potential in Ibadan, Nigeria, Based on Weibull Distribution Function", Pacific Journal of Science and Technology, 9(1), pp. 110-119, 2008.

[11] Odo, F. C., Offiah, S. U. and Akubue, G. U. "Wind Resource Assessment of Enugu and Owerri for 
Wind Power Development", Nigerian Journal of Solar Energy, Vol. 26, pp. 1-6, 2015.

[12] Okoro, I. O., Chikuni, E. and Govender, P. "Prospect of Wind Energy in Nigeria" https://www.researchgate.net/_ publication/ 228827644_Prospects_of_wind_energy in Nigeria. Accessed on December 23, 2015.

[13] Akorede, M. F., Ibrahim, O., Amuda, S. A., Otuoze, A. O., Olufeagba, B. J. "Current Status and Outlook of Renewable Energy Development in Nigeria", Nigerian Journal of Technology, Vol. 36, No. 1, pp. $196-212,2017$.

[14] Ministry of Science and Technology, Nigeria. "3D Wind Map of Nigeria $80 \mathrm{~m}$ above the Ground".

[15] Sathyajith, M. Wind Energy: Fundamentals, Resource Analysis and Economics: Springer-Verlag New York, 2006.

[16] Akpinar, E .K. and Akpinar, S. "Statistical Analysis of Wind Energy Potential on the Basis of the Weibull and Rayleigh Distributions for AginElazig, Turkey", J. Power \& Energy, 218:pp. 557-565, 2004.

[17] Seguro, J. V. and Lambert. T.W. "Modern Estimation of the Parameters of the Weibull Wind Speed Distribution for Wind Energy Analysis ", J. Wind Eng. and Ind. Aerodynamics, 85: pp. 75-84, 2000.

[18] Sathyajith M, Geetha S and Chee M "Analysis of Wind Regimes and Performance of Wind Turbines", Faculty of Science, University of Brunei Darussalam, Jalan Tungku Link, Gadong, BE1410 Negra, Brunei Darussalam, 2011.

[19] Indhumathy, D, Seshaiah, C. V. and Sukkiramathi, K. "Estimation of Weibull Parameters for Wind speed calculation at Kanyakumari in India", International Journal of Innovative Research in Science, Engineering and Technology, Vol. 3. pp. 1-6, 2014

[20] Khandaker, I., Natthawud, D. and Tanate, C. "An Approach to Determine the Weibull Parameters and Wind Power Analysis of Saint Martin's Island, Bangladesh" School of Renewable Energy, Maejo University, Sansai, Chiang Mai 50290, Thailand. 2016
[21] Stevens, M. J. and Smulders, P. T. "The estimation of the parameters of the Weibull wind speed distribution for wind energy utilization purposes", Wind Engineering, Vol. 3(2), pp.132-45, 1979.

[22] Akdag, S .A. and Ali, D. A. "New method to estimate Weibull parameters for Wind energy applications", Energy convers Manag. 5, pp.1761-1766, 2009.

[23] The Royal Academy of Engineering. "Wind Turbine Power Calculations" RWE npower renewables. www.engineeringtoolbox.com Accessed on December 15, 2016.

[24] Gipe, P. Wind Power: Renewable Energy for home Farm and Business, Chelsea Green, USA, 2004.

[25] Hughes, Tim "Lesson Number 1, Oklahoma Wind Power Tutorial Series". Environmental Verification and Analysis Center, The University of Oklahoma, 2000.

[26] Boyle, G., ed. Renewable Energy: Power for a Sustainable Future. $2^{\text {nd }}$ Ed. New York: Oxford University Press Inc. 2004

[27] Lu X., Tchou, J., McElroy M. B. and Nielsen, C. P. "The impact of production tax credits on the profitable production of electricity from wind in the U.S", Energy Policy, 7(39), pp. 4207-4214, 2011.

[28] Dike, V. N., Chineke, C. T., Nwofor, O. K. and Okoro, U. K. "Estimating wind energy potential in some coastal cities of the Niger-Delta Region of Nigeria", Pacific Journal of Science and Technology, Vol. 12, Number 1, pp. 598-604, 2011.

[29] Ayodele, T. R., Ogunjuyigbe, A. S. O., and Amusan, T. 0 . "Wind power utilization assessment and economic analysis of wind turbines across fifteen locations in the six geographical zones of Nigeria", Journal of Cleaner Production, pp.1-9, 2016.

[30] Ohunakin, O. S. "Wind characteristics and wind energy potential assessment in Uyo, Nigeria", Journal of Engineering and Applied Sciences, 6 (2), pp. 141-146, 2011. 